\title{
Real Interest Rates: What Accounts for Their Recent Rise?
}

\author{
A. Steven Holland
}

$\mathbf{N}$

OMINAL interest rates have risen to unprecedented levels in the last five years, and the common perception is that expected real rates of interest rates minus expected inflation - have risen as well. These higher rates are blamed for a variety of economic ills including reduced capital investment and slowdowns in such interest-sensitive sectors as housing and automobiles.

This paper is concerned, first, with establishing that real interest rates have indeed been higher during the 1980s than in the previous two decades and, second, with examining possible causes of this major shift. Potential causes include changes in the expected rate of inflation, monetary policy, the state of the economy, taxes, federal budget deficits and the declining relative price of energy.

\section{ESTIMATES OF BEFORE- AND AFTER-TAX REAL INTEREST RATES}

The real interest rate is not known with certainty at the time a security is purchased, but the purchaser has an expectation of it. The nominal interest rate, $i$, is the sum of the expected real rate of interest, $r$, and the expected rate of inflation, $\dot{\mathrm{p}}^{\mathrm{e}}$ :

$$
\text { (1) } \mathbf{i}=\mathbf{r}+\dot{\mathbf{p}}^{\mathrm{e}}
$$

The expected real rate, thus, can be estimated according to the formula:

$$
\text { (2) } \mathrm{F}=\dot{\mathrm{i}}-\dot{\mathrm{p}}^{\mathrm{e}} \text {, }
$$

as long as an estimate of the expected inflation rate is available.

A. Steven Holland is an economist at the Federal Reserve Bank of St. Louis. Jude L. Naes, Jr., provided research assistance.

This equation is a widely used approximation of the "Fisher equation:" See Fisher (1965).
Proxies for the expected rate of inflation frequently are based on weighted averages of past inflation rates or the predicted values from regression equations in which the inflation rate depends on past inflation rates, past rates of money growth and a number of other variables..$^{2}$ Because empirical results can be sensitive to assumptions about the way expectations are formed, however, a potentially more fruitful approach is to use "observed" inflation forecasts to estimate expected inflation. ${ }^{3}$ In this article, data from surveys of both short- and long-term inflation expectations are used to estimate short- and long-term expected real rates of interest.

This analysis oversimplifies the problem, since it applies only to the expected real before-tax yield. Since interest payments are taxable as earned income, the expected real after-tax yield $\left(\mathrm{r}^{*}\right)$ is:

$$
\text { (3) } \begin{aligned}
\mathbf{r}^{*} & =\mathbf{i}-\mathrm{ti}-\dot{\mathbf{p}}^{\mathrm{e}} \\
& =(1-\mathrm{t}) \dot{\mathrm{i}}-\dot{\mathbf{p}}^{\mathrm{e}}
\end{aligned}
$$

where $t$ is the marginal tax rate. An estimate of the average marginal tax rate on personal income is used below to estimate expected after-tax real interest rates.

The estimates presented in this article are intended to represent the pattem of recent real interest rate movements, not to provide completely accurate estimates of real interest rates at any point in time. Potential sources of error in the estimates include but are not limited to : (a) measurement error in calculating the expected rate of inflation, (b) the effects of different

\footnotetext{
2As pointed out by Santoni and Stone (1982), however, the difficulty with this procedure is that any change in economic policy or any structural change or "shock" that affects inflation expectations will not be incorporated in the estimate of expected inflation.

3For an example of the sensitivity of empirical results to assumptions about expectations formation, see Hoiland (1984).
} 
Chart 1

\section{Nominal and Real 1-Year Interest Rates}

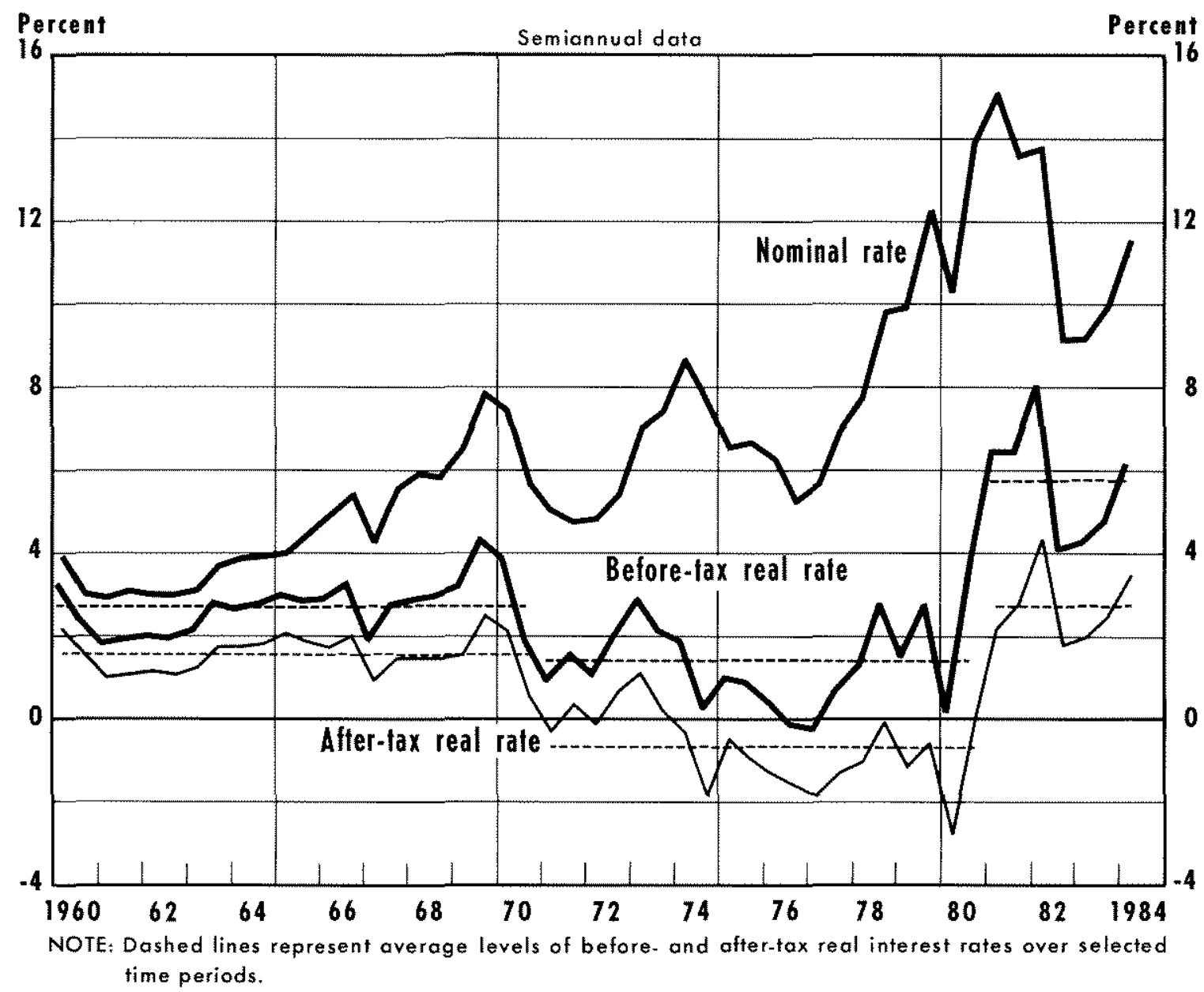

marginal tax rates across market participants and (c) the difference between the marginal tax rate expected to hold at the time interest payments are received and the current rate. ${ }^{4}$ Whenever real interest rates are referred to in the following discussion, it will mean expected real interest rates.

\section{Estimates of Short-Term Real Interest Rates}

Chart 1 plots nominal returns and estimates of the before-and after-tax real returns on one-year Treasury securities, based on one-year inflation forecasts from

In addition, the return that is relevant for decision-making depends on risk and the tax burden on alternative uses of funds. More will be said about risk later in the article. See Ezrati (1982) and Mehra (1984) for discussions of the implications of taxes on alternative uses of funds. the Livingston survey from 1960 to the first half of $1984 .{ }^{5}$ Between 1960 and 1970 , the nominal rate rose from around 3 percent to over 7 percent. Estimates of

5Joseph Livingston of The Philadelphia Inquirer conducts a survey of economists each spring and fall, requesting respondents to indicate their predictions of the consumer price index (CPI). Because the survey results published, for example, in June contain predictions for the following December and June, Livingston refers to them as six-and 12-month-ahead forecasts as this article does. Because the respondents to the June survey are thought to know only the April $\mathrm{CPI}$, however, they are actually predicting eight- and 14 -month rates of change. For a detailed discussion of the Livingston expectations data, see Carlson (1977). This article uses the data in Carlson's revised form updated to the present. The nominal interest rates used in the charts and table are the quarterly averages of the rates for the quarter in which the Livingston survey was taken. The same calculations were made for six-month Treasury bills based on sixmonth inflation forecasts. Since the pattern of movements was nearly identical, however, only the one-year rates are reported. The estimate of the average marginal tax rate comes from Chase Econometrics. 
Chart 2

Nominal and Real 10-Year Interest Rates

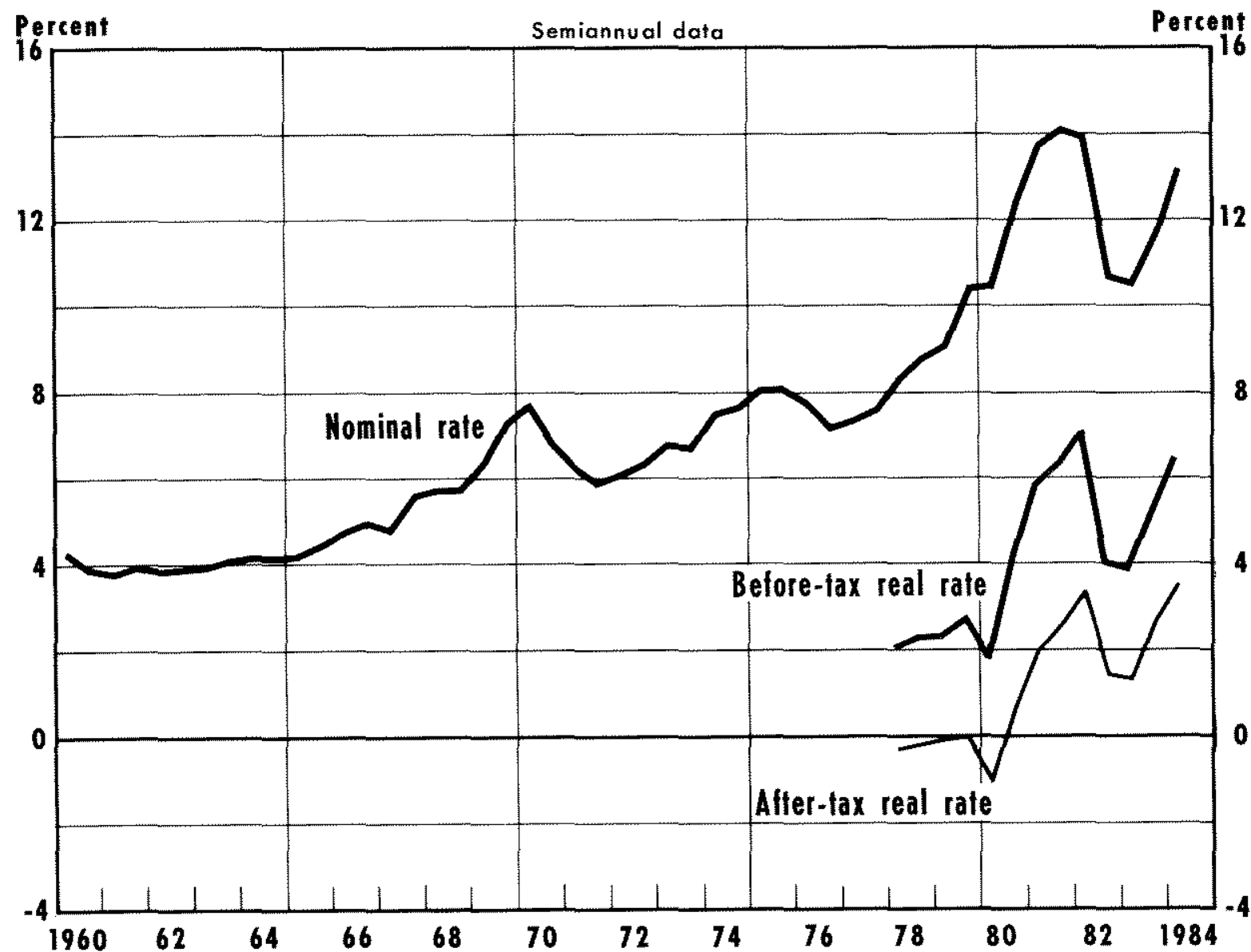

the expected real rate indicate this was due primarily to higher expected inflation, since both the beforeand after-tax real rates appear to have risen only slightly, if at all, over the period.

Between 1971 and 1980, short-term nominal interest rates, on average, were much higher than in the 1960s; real rates, for the most part, were lower. In fact, estimated before-tax real rates were below 1 percent from the second half of 1974 to the first half of 1978 and were even negative in late 1976 and early 1977 . After-tax real rates were negative for nearly the entire period from 1974 to 1980 . Nominal rates increased dramatically after 1977, with increases of about 200 basis points occurring in late 1978 and again in late 1979. These increases, however, served only to bring real rates closer to the levels that had prevailed before 1974 .

From late 1979 to early 1982, short-term nominal interest rates were higher than at any time during the
1960 s or 1970 s. Short-term real interest rates, however, did not break with precedent until 1981 when beforetax real rates climbed above the 6 percent level; they continued to rise through early 1982. After-tax real rates behaved in a similar fashion and, on average, have been higher since 1981 than in the previous two decades. The difference is not as great, however, as it is for before-tax real rates. Both nominal and real rates have declined since early 1982 , but they remain at very high levels relative to past history.

\section{Estimates of Long-Term Real Interest Rates}

We expect long-term real interest rates to behave in a manner broadly similar to short-term real rates; if short-term rates rise, long-term rates are forced up so that real yields over any holding period are compara- 


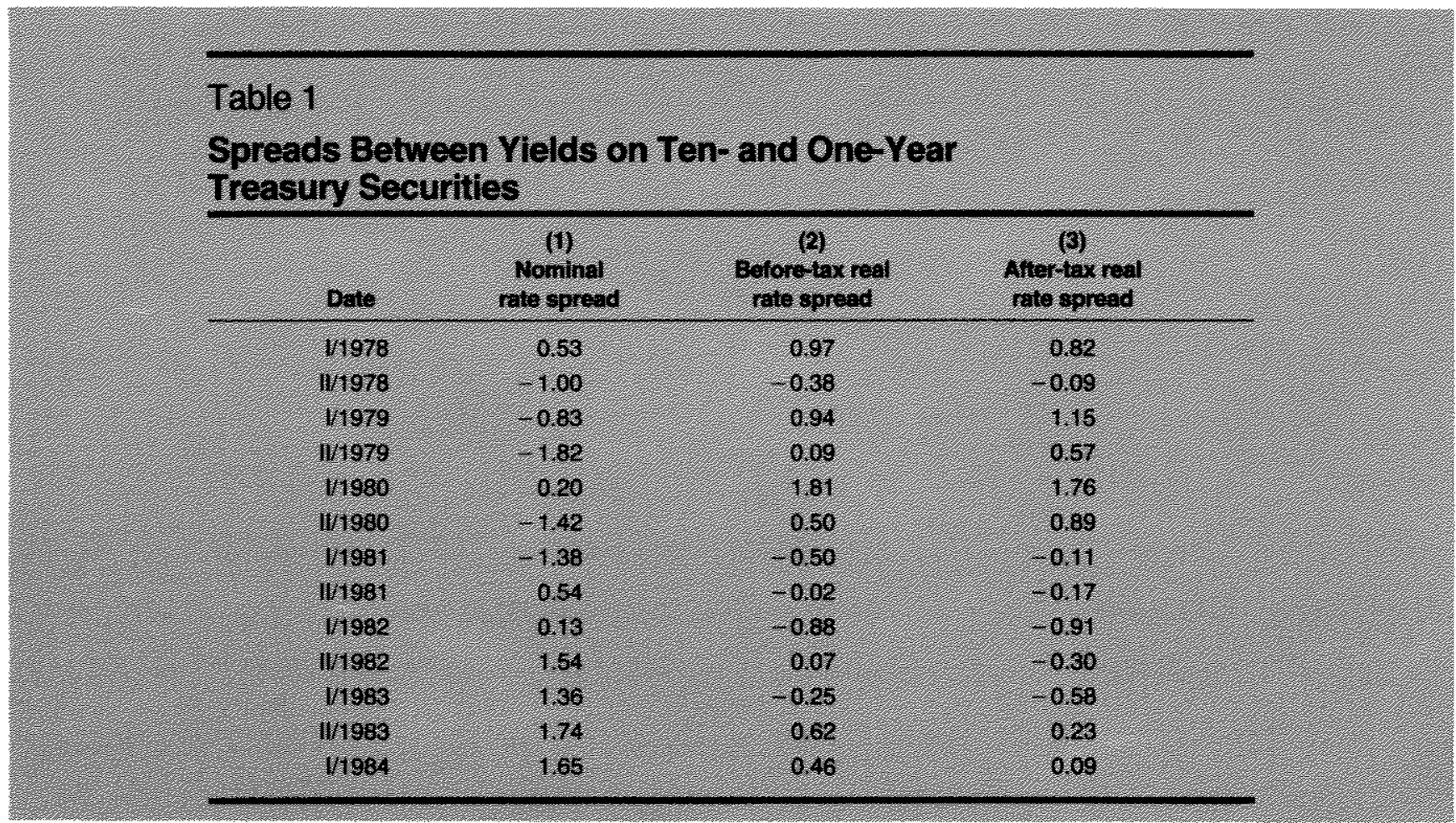

ble whether one holds short- or long-term bonds. Because of data limitations, however, it is much more difficult to get an accurate representation of the mar ket's expectation of inflation over the distant future than over the near future? In fact, it is only since 1978 that a survey of expected inflation over periods substantially longer than a year has been undertaken. The survey, known as the Decision-Makers Poll, provides estimates of expected inflation over the next five and 10 years.

-This assumes the absence of segmented markets. In other words, there is a high degree of substitutability between short- and longterm securities. This is not meant to imply that the term structure of interest rates does not change over time, only that short- and longterm interest fates behave in a broadly simila fashion.

IIt is also more difficult to know the appropriate tax rate to use in calculating the after-tax yield, since interest payments are made much farther in the future.

*Richard Hoey of Drexel Burnham Lambert, Inc., conducts this survey of institutional portfolio managers. Each respondent predicts the rate of change of consumer prices over the next five years and over the five subsequent years. The average of the two provides the estimate of expected inflation over the next 10 years.

Since 1980 , the survey has been conducted at least four times a year. To facilitate comparison with the shorter-term real interest rate estimates, we use data from surveys taken as close as possible to the dates of the Livingston surveys. There is never more than one month's difference in the dates of the surveys of the short- and longterm inflation expectations used in this paper. In 1978 and 1979 there was only one survey in each year (taken near the middle of the year). These two surveys provided data for the estimates of longterm inflation expectations for the first halves of 1978 and 1979. Estimates for the second halves of both years were calculated by interpolation.
Chart 2 plots the nominal yield on 10-year Treasury securities since 1960 , as well as estimates of the 10 year, before- and after-tax real rates since 1978 based on the mean inflation forecasts from the survey. As expected, the pattern of movements in long-term nominal rates during the 1960 s and 1970 s is similar to that in short-term rates. In particular, when shortterm nominal rates shot upward in the late 1970s, so did long-term nominal rates. Long-term real rates also reached heights comparable to those of short-term real rates in 1981 and $1982 .^{9}$ Thus, it appears that the increase in long-term real rates occurred at roughly the same time and was of roughly equal size as the increase in short-term real rates.

\section{The Term Structure of Real Interest Rates}

Nominal long-term rates have been substantially above nominal short-term rates since 1982 , reversing the pattem from the late 1970 s and early 1980s. This is illustrated in column 1 of table 1 , which gives the difference between the yields on 10-year and one-year Treasury securities since 1978. Comparable differences for before- and after-tax real rates, respectively, are presented in columns 2 and 3 of the table.

The estimated real term structure tells an entirely different story than the nominal term structure. There

'Five-year rates exhibited a similar pattern. 
Figure 1

Initial Equilibrium in the Markef for Laanable Funds

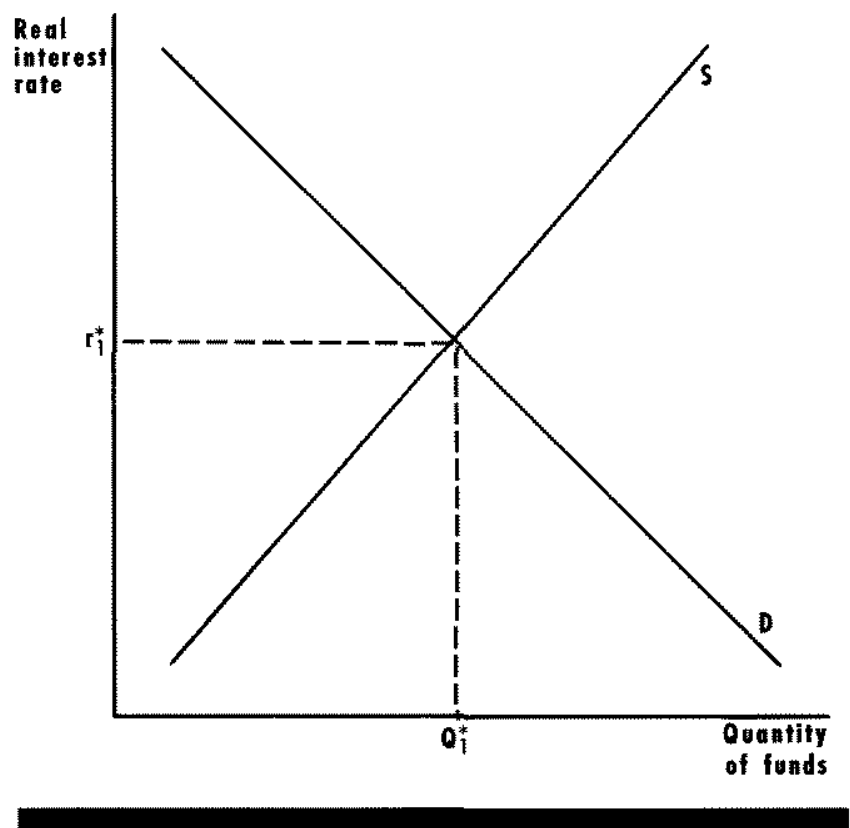

is, for the most part, very little difference between short- and long-term real rates. In other words, the real "yield curve" - the relationship between the term to maturity and the real rate of interest on securities has been much flatter in recent years than the nominal yield curve. The average absolute difference between the one-and 10-year nominal rates from 1978 to 1984 is 109 basis points; for before-tax real rates, it is $\mathbf{5 8}$ basis points, while for after-tax real rates it is 59 basis points. These figures imply that long-term real rates have not differed substantially from short-term real rates in recent years. ${ }^{10}$

\section{WHY DHD REAL INTEREST RATES RISE?}

The real interest rate is determined by the interaction of the supply of and demand for loanable funds. The quantity of funds available for lending the quantity supplied) increases as the real rate of interest increases. The quantity that people wish to borrow (the quantity demanded) decreases as the real rate increases. The equilibrium real rate is that for which the quantity demanded and quantity supplied are equal.

10Notice that long-term inflation expectations were substantially lower than short-term inflation expectations from 1978 to early 1981, a period of predominantly rising inflation. This pattern has been reversed for late 1981 through early 1984 , a period of generally declining inflation.
Figure 2

The Eflects of an Increase in the Supply of and Reduction in the Demand for Loanable Funds

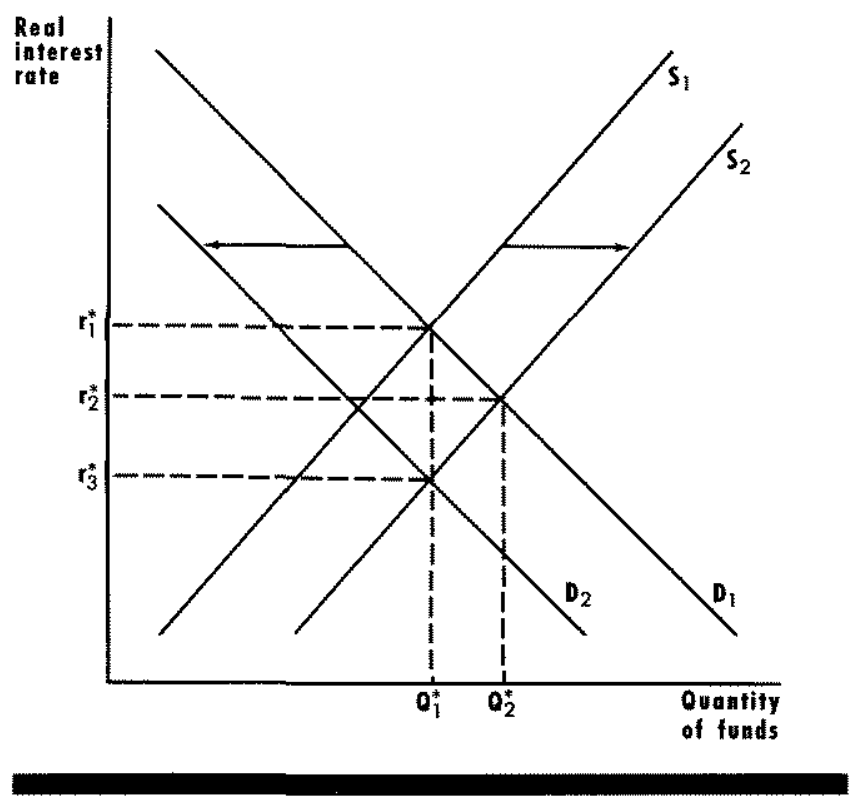

In figure 1, this occurs at the real rate $r_{1}^{*}$, where $S$ represents the supply curve and $D$ represents the demand curve. Factors that affect the positions of the supply and demand curves determine the equilibrium rate. Potentially, these factors include the expected rate of inflation, monetary policy, the state of the economy, taxes, federal budget deficits and the declining relative price of energy. The potential impact of each of these factors on real interest rates is discussed below.

\section{Expected Inflation}

We know that expected inflation affects nominal interest rates. In fact, our real rate estimates are derived by subtracting the expected inflation rate from the nominal interest rate. Changes in expected inflation, however, also have the potential to alter real interest rates. One reason, associated with Mundell (1963), is that higher expected inflation causes people to transfer part of their assets from money to (higher) interest-earning assets, thereby increasing the supply of loanable funds and driving down the real interest rate. This occurs because money provides a very low or negative real return during times of inflation, whereas the return on interest-earning assets generally keeps better pace with expected inflation. A simim lar notion, associated with Tobin (1965), is that higher expected inflation causes people to shift part of their money balances into real capital. This induces net 
investment in capital that ultimately depresses the marginal return on capital, reducing the demand for loanable funds and the real interest rate.

An additional argument, based on the effect of expected inflation on the return to capital investment is $_{f}$ associated with Feldstein and Summers (1978): Higher inflation drives up the replacement cost of capital, while current tax law provides for depreciation allowances for businesses based on the historical cost of capital. Therefore, higher expected inflation results in a lower expected real return on capital investment, reducing the demand for loanable funds and, consequently, the real interest rate.

These effects are illustrated in figure 2 . The Mundell effect shifts the supply curve from $S_{1}$ to $S_{2}$ lan increase in supply), resulting in a decline in the equilibrium real rate of interest from $r_{1}^{*}$ to $r_{z}^{*}$. Similarly, the Tobin and the Feldstein-Summers effects shift the demand curve from $\mathrm{D}_{1}$ to $\mathrm{D}_{2}$ (a reduction in demand), resulting in a decline in $r^{*}$ (to $r_{3}^{*}$ if both shifts occur $)$.

There is, however, a potential positive effect of expected inflation on the real interest rate that works through the personal income tax system. ${ }^{11}$ Under the assumption that people try to maintain a constant after-tax real rate, higher expected inflation leads to higher before-tax real interest rates since taxes are assessed on the nominal return. ${ }^{12}$ Thus, the higher the nominal return, the greater the spread between the before- and after-tax real rates, all other things equal. The widening of the spread between before- and aftertax real rates as the nominal interest mate increases can be seen in chart 1 , where the averages of the before- and after-tax real rates for the periods 1960-70, $1971-80$ and $1981-84$ are given by the dashed lines.

Therefore, with the combination of the MundellTobin and Feldstein-Summers effects and the income tax effect, it is not possible to say a priori whether an increase in expected inflation leads to higher or lower before-tax real interest rates, although we expect it to

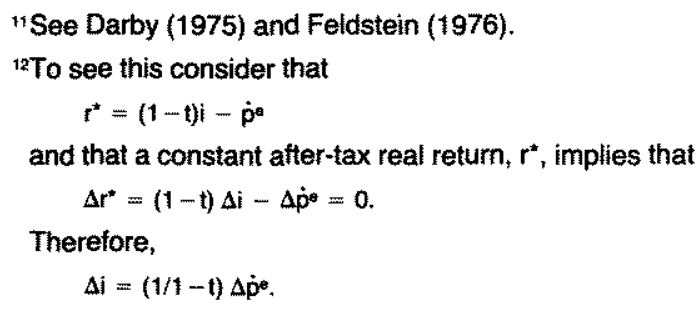

With the tax rate, $t$, between 0 and 1 , this implies that the change in the nominal interest rate, $\Delta \bar{i}$, is greater than the change in the expected inflation rate, $\Delta \dot{p}^{a}$. If the tax structure is progressive, then higher expected inflation results in an even wider spread between before- and after-tax real rates. cause lower after-tax real ates ${ }^{13}$ From 1960 to 1980 , the correlation between expected inflation and both before- and after-tax real rates on one-year Treasury securities was negative and statistically significant: -0.38 for the before-tax rate and -0.81 for the aftertax rate. This provides support for the Mundell-Tobin and Feldstein-Summers effects. From 1981 to 1984, however, the correlation has actually been positive for the before-tax rate and essentially zero for the after-tax rate. The same is true for the correlation between inflation expectations and long-term real rates over the 1981-84 period. ${ }^{14}$ Furthermore, during the period of rapidly rising real rates from 1980 to 1982 , long-term inflation expectations were also rising. Thus, though the evidence on the effect of expected inflation on real interest rates from simple correlations is mixed, it does not appear that changes in expected inflation were a major factor in the recent rise in real interest rates.

\section{Monetary Policy}

The effect of monetary policy on real rates of interest is a subject of considerable controversy. Textbooks typically describe the impact of an increase in money supply on the real rate as follows: An increase in the money supply relative to money demand creates an excess supply of money; in response, individuals increase their purchases of securities and goods until the interest rate declines by enough to induce them to hold the larger amount of money. Thus, the supply of loanable funds increases, driving down the real interest rate. Furthermore, an expansionary monetary policy leads to short-term increases in real income due to the increased demand for goods, which has two effects that influence real rates in opposite directions: (1) the level of savings increases, putting downward pressure on the real rate, and (2) the demand for money increases, causing the real rate to rise. ${ }^{15}$

One consequence of increasing the growth rate of the money supply, however, is a rise in future rates of inflation and also in expected future rates of inflation.

\footnotetext{
See Makin and Tanzi (1983).

14The correlation coefficients for $1981-84$ are: for the one-year before-tax real rate, 0.48 ; for the one-year after-tax real rate, -0.06 ; for the 10-year before tax real rate, 0.38; for the 10-year after-tax real rate, -0.04

${ }^{15}$ For more detail, see Santoni and Stone, and Brown and Santoni (1983). The theory of rational expectations states that a fully anticipated change in the money supply will have no effect on real interest rates. When people torecast money growth and future inflation in an optimal manner - by using all of the information currently available at sufficiently low cost - then the monetary authority is powerless to affect real behavior of any kind unless it is able to fool the public. This implies that only an unanticipated change in money supply affects the real interest rate. See Fischer (1980).
} 


\section{Chart 3 \\ 2-Quarter M1 Growth and 1-Year Real Interest Rate}

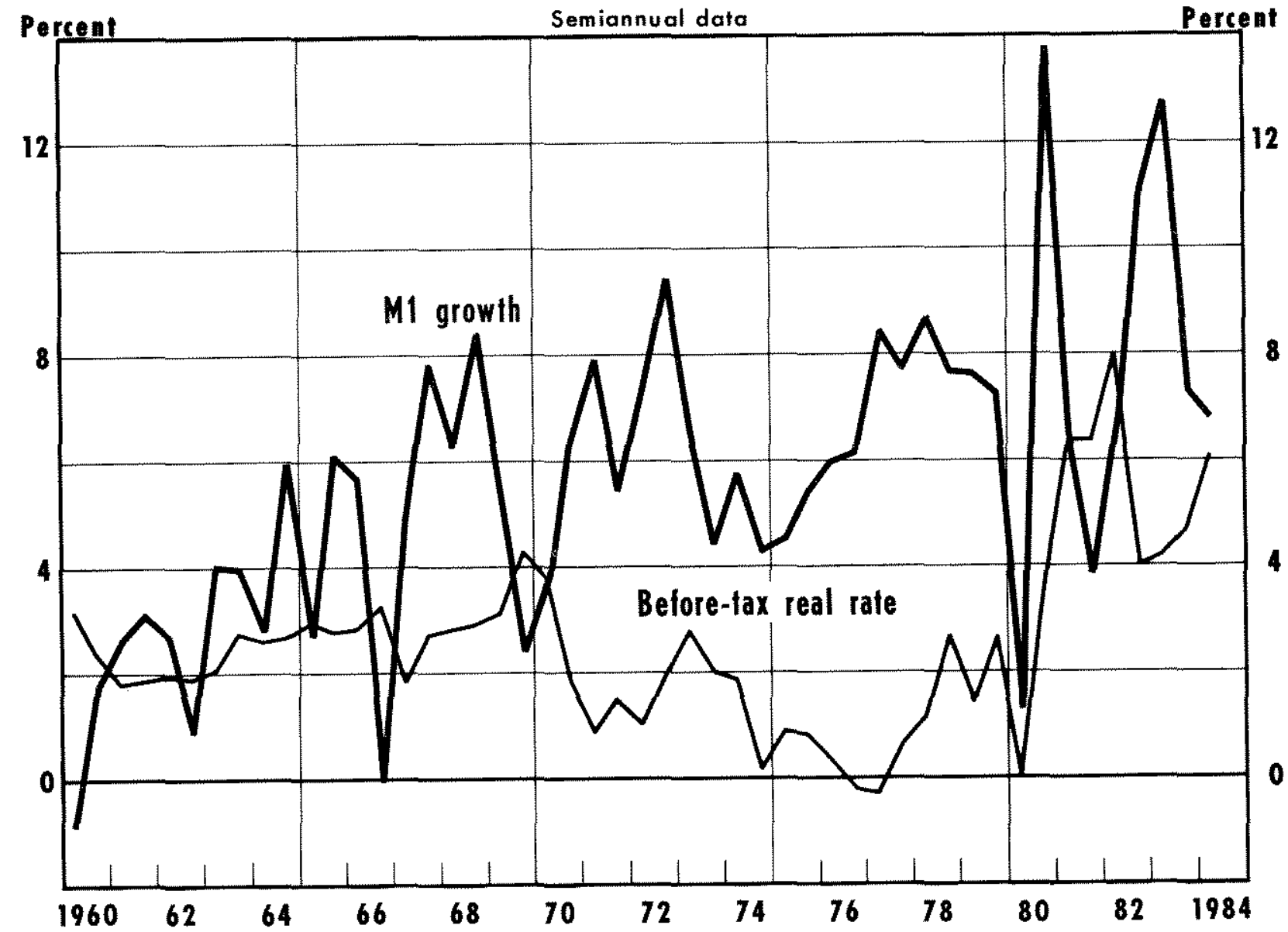

Therefore, the effect of increased growth of the money supply on nominal rates is likely to be positive in the long run even if its immediate effect on real rates is negative.

Empirical evidence suggests that there is little, if any, long-term effect of changes in the money supply on real interest rates. Hafer and Hein (1982) found that an initial negative effect of higher money growth on estimates of real interest rates was completely offset one quarter later. Similarly, Santoni and Stone (1982) found no evidence to link money growth and real rates over the long term..$^{16}$

Chart 3 plots the two-quarter growth rate of M1 along with our estimate of the before-tax real interest ${ }^{16}$ Carison (1982) actually finds a weak positive association between
money growth and real interest rates. rate on one-year Treasury securities. The first point to make is that the correlations between money growth and the real interest rate series are negligible for the sample period used in the chart. ${ }^{17}$ it is true, however, that real rates of interest began to rise in 1980 just after a tremendous reduction in two-quarter M1 growth. This reduction was followed by an equally large increase in $M 1$ growth, but real interest rates continued to climb nonetheless.

The data illustrated in the chart suggest another possible role for monetary policy in the determination

TThe correlation coefticient for two-quarter M1 growth and the before-tax reak interest rate on one-year Treasury securities for $1960-$ 84 is 0.076 . The correlation between money growth and the beforetax real 10-year rate for 1978-84 is -0.071 . Correlations with the after-tax yields on the same securities for the same time periods are -0.157 and -0.004 , respectively. 
of real interest rates: more variable money growth leads to higher real rates. The explanation for this is that the instability created by highly variable money growth makes for increased uncertainty about future retums on both short-and long-tem interest-earning assets and capital and raises the demand for money relative to these assets. This is, in effect, a reduction in the supply of loanable funds, which causes an increase in real interest rates. ${ }^{18}$

Another way to state this is: lenders, if they are riskaverse, require that a greater "risk premium" be added to interest rates in order to offset the greater uncertainty associated with the future real return. ${ }^{\text {: }}$ The effect of monetary variability on real interest rates is not completely unambiguous, however, since risk-averse borrowers reduce their demand for loanable funds as uncertainty increases. A recent empirical study by Mascaro and Meltzer (1983) suggests that the overall effect of monetary variability on nominal interest rates is positive. Since the variability of money growth should not affect expected inflation, it follows that the effect on real interest rates is positive as well, ${ }^{20}$

A casual glance at chart 3 suggests that money growth became substantially more variable in 1980 , the same year that real rates of interest began to rise. The standard deviation of two-quarter M1 growth is substantially higher for 1980-84 than for 1960-79, 4.1 percent compared with 2.5 percent. The source of greater monetary variability is an unsettled issue, but many analysts attribute it to the change in Federal Reserve operating procedure that occurred in October 1979.2 Other events also may have contributed to the rise in monetary variability including the innovation in financial markets (such as the introduction of NOW, Super NOW and money market deposit accounts) and the imposition and removal of credit controls in 1980.2

Thus, it appears that an increase in the variability of money growth in 1980 contributed to the increase in

\footnotetext{
18 See Friedman and Schwartz (1963).

19 The analysis assumes that it is not possible to diversify one's holdings in a manner that completely oftsets the greater risk associated with monetary variability.

oMascaro and Meltzer estimate the variability of unanticipated money growth, which turns out to be highy correlated with the variability of actual money growth.

2‡The Federal Reserve announced on October 6, 1979, it woutd place less emphasis on confining variations in the federal funds rate and more emphasis on reserve aggregates as a sign of its commitment to longer-run restraint on money growth.

2See Hafer (1984) for a discussion of how financial innovations may have affected the accuracy of $\mathrm{M} 1$ as a measure of transaction balances.
}

real rates of interest that occurred in 1980 and 1981 . Furthemore, there is as yet no indication that the short-run instability of money growth was much affected one way or another by the Federal Reserve's shift to a more judgmental operating procedure in the fall of 1982, and real interest rates have yet to return to their pre-1981 levels. ${ }^{23}$

\section{The State of the Economy}

When the economy enters a recession, business firms experience excess capacity, and the need for additional capital is reduced. A reduction in both the demand for loanable funds and the real rate of interest follows. As the economy recovers, some firms begin to push toward their capacity constraints, requiring additional investment and increasing the demand for funds. Thus, higher real interest rates tend to accompany an expansion.

Chart 4 plots a measure of the amount of "slack" in the economy, the GNP gap, along with our estimate of the before-tax real rate on one-year Treasury securities. The evidence suggests that the state of the economy helps to explain movements in real interest rates both before and after the, recent upward shift in real rates, but the shift itself appears to have little to do with overall economic conditions. The GNP gap has a correlation of -0.56 with the before-tax real rate for the period $1960-80$, and -0.44 for $1981-84 .^{24}$

\footnotetext{
${ }^{23}$ As evidence that the money supply continues to be highly variable, consider the behavior of M1 during 1983 and 1984, M1 grew during the first two quarters of 1983 at a 12.8 percent rate and during the second two quarters of 1983 at a 7.3 percent rate. Similarly, in 1984 the growth rate of M1 was 6.8 percent in the first half of the year, compared with -0.4 percent from June to October.

It is generally recognized that the Federal Reserve altered its operating procedure again in late 1982 . The post-1982 procedure is not the same as the pre-1979 procedure, however. See Wallich (1984). Anothez effect of the 1979 change in operating procedure was an increase in the day-to-day variability of nominal interest rates, which adds an additional element of risk in securities markets. This increased variability occurred in late 1979 , however, while real interest rates did not begin to rise until late 1980 . In addition, the federal override of state usury ceilings effective in March 1980 may have contributed somewhat to higher real interest rates, although there is no reason to think this action would push real rates to levels higher than those during previous periods (such as most of the 1960 s and early 1970s) when these cellings were not binding.

${ }^{24}$ The measure of the GNP gap is the difference between potential and actual GNP as calculated by the Council of Economic Advisers. To get data for 1984 , potential GNP was assumed to grow at its average rate for $1960-83,3.44$ percent. For the 10-year before-tax real rate, the correlation for $1981-84$ is -0.55 . For after-tax real rates, the correlations are -0.62 for the $1960-80$ period and -0.13 for the $1981-84$ period for the one-year rate and -0.37 for the $1981-$ 84 period for the 10-year rate.
} 


\section{Chart 4}

\section{GNP Gap and 1-Year Real Interest Rate}

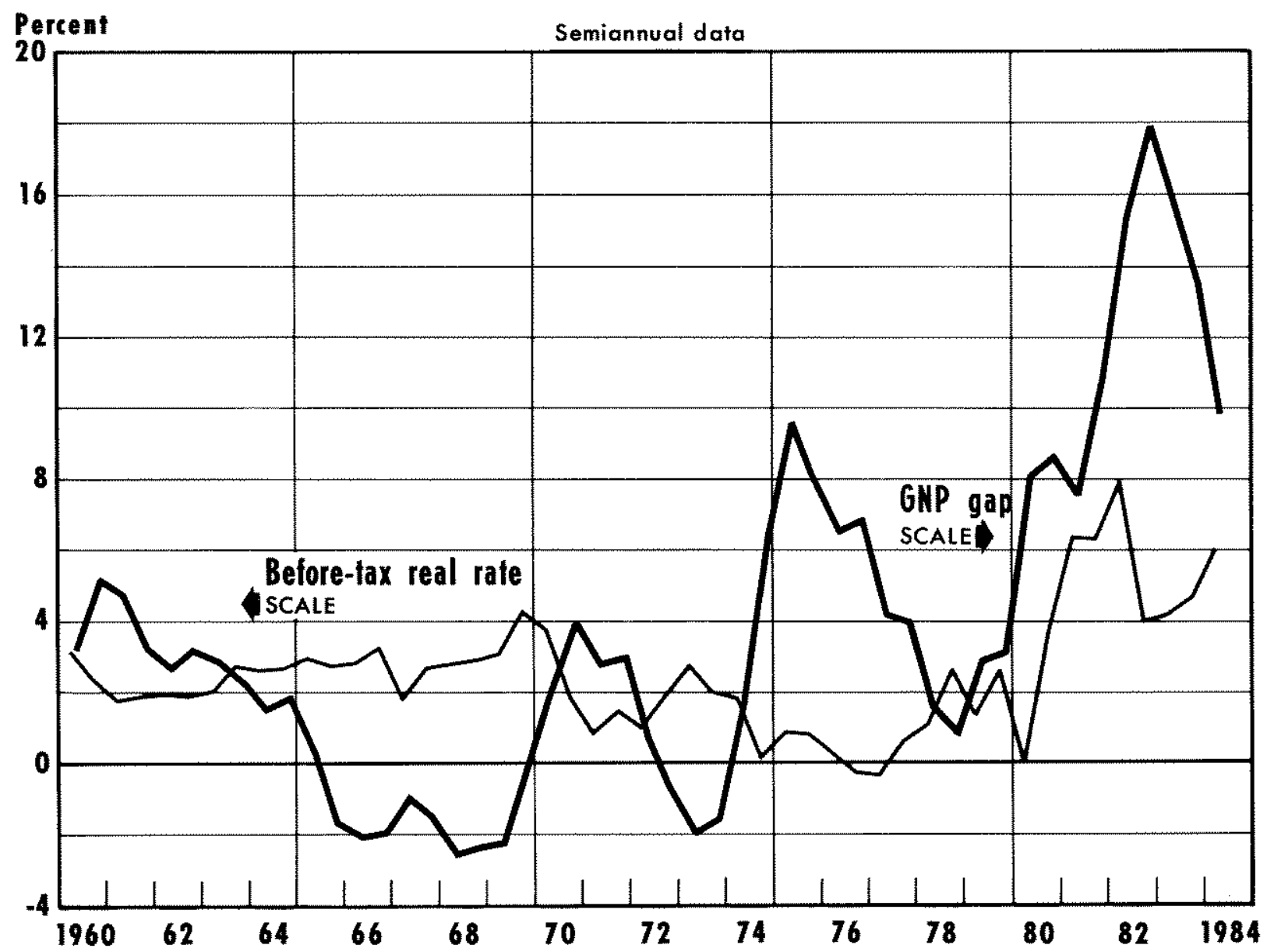

\section{Business Taxes}

As noted above, the higher the return on investment in physical capital, the greater the demand for loanable funds. A tax on business profits reduces the real return on investment and the demand for loanable funds, thereby lowering real interest rates. A tax on business profits is not the only business tax that affects investment and the real interest rate, however. Businesses often receive tax credits or deductions from taxable income for certain types of investment expenditures. Furthermore, tax deductions to offset the depreciation of capital equipment and structures can affect the investment decision and real rates, since these depreciation allowances may or may not reflect the true depreciation of the capital. If the allowances overstate the depreciation over a period of time, they tend to spur additional investment, driving up the demand for loanable funds and the real rate of interest. If allowances provide for smaller deductions than the actual loss from depreciation, they hinder investment and real rates are reduced..$^{25}$

The Economic Recovery Tax Act of 1981 was designed to spur investment, primarily by altering the way in which depreciation is treated for tax purposes. The magnitude of the effect of the act on investment is a controversial issue, but there is fairly strong evidence

\footnotetext{
z5see Ott (1984).
} 
that it spurred investment spending. For instance, the growth rate of real nonresidential fixed investment as a percentage of real GNP was 8.7 percent over the expansionary period from the fourth quarter of 1982 to the second quarter of 1984, up from an average of only 1.5 percent over similar periods following the previous six recessions. ${ }^{26}$

One problem, however, with concluding that the new tax legislation is a primary cause of higher interest rates is that the legislation was not passed until August 1981 (although its provisions were retroactive to the beginning of 1981 , while the shift in real rates began in 1980 and was mostly complete by August 1981. For this legislation to have been the primary factor in the recent rise in real interest rates, the passage of the legislation must have been predicted and the demand for loanable funds increased many months in advance as the predicted future return on capital investment rose. On the other hand, this legislation could have contributed both to the rise in real rates that occurred in late 1981 and early 1982 in the face of a severe recession and to the maintenance of relatively high real interest rates right up to the present.

\section{Federal Budget Deficits}

Govemment borrowing represents an increase in the total demand for loanable funds. This suggests that real interest rates rise as the size of the govern" ment budget deficit increases in real terms. One rarely sees a positive comelation between the size of deficits and the levels of interest rates, however. This is probably because they respond in opposite directions to changes in economic conditions; deficits tend to rise during business recessions and fall during expansions (because tax revenues and outlays for transfer payments are sensitive to the state of the economy), while interest rates typically fall during recessions and rise during expansions. ${ }^{27}$

As for the recent rise in real interest rates, it is clear from chart 5 that the recent dramatic increase in the cyclically adjusted budget deficit did not occur until late 1982 , by which time real and nominal interest rates had begun to fall. A closer look at the chart

${ }^{26}$ The six previous expansionary periods were IV/1949-II/1951, II/1954-IV/1955, II/1958-IV/1959, I/1961-III/1962, IV/1970-II/1972 and $1 / 1975-11 / 1976$. The difference between the growth of the investment-GNP ratio in the current recovery and the average growth in the six previous recoveries is statistically significant.

${ }^{27}$ See Tatom (1984). indicates that two major increases in the size of the cyclically adjusted deficit have occurred in recent years: one in 1975 and the other in 1982. Neither was associated with rising real interest rates.

This does not necessarily imply that deficits have no effect on real interest rates. Since interest rates are based on expectations, expected future deficits could have an impact on today's real interest rates. If one assumes the budget projections of the Congressional Budget Office (CBO) are representative of the market's expectation of future deficits, however, then deficit projections do not appear to have been the major instigator of the recent rise in real interest rates. The CBO report published in July 1981 projected a 1982 deficit of less than $\$ 30$ billion and surpluses in the next four years growing to over $\$ 200$ billion by $1986 .{ }^{2 k}$ Recall that at the time this report was written, our estimates of both short-and long-term before-tax real interest rates were already far in excess of historical noms and after-tax real rates had risen to near their previous peaks. By February 1982, the CBO had altered its projections and was predicting a deficit of nearly $\$ 200$ billion in 1983 , growing to nearly $\$ 300$ billion by $1987^{29}$ Yei 1982 was a year of generally falling real and nominal interest rates..$^{30}$ Like the change in the tax laws, however, expectations of future deficits may be helping to keep real interest rates at levels that are quite high relative to past history.

\section{Declining Relative Price of Energy}

Finally, it has been suggested that drastic increases in the relative price of energy contributed to the low real interest rates of the 1970 s, which would imply that the generally falling relative price of energy of the 1980 s has contributed to higher real interest rates. ${ }^{31}$ The argument is that the demand for capital fell during the 1970 s because of a reduction in the supply of

\footnotetext{
${ }^{2}$ Congressional Budget Office (1981). Carlson (1983) discusses possible sources of bias in the CBO's budget projections.

${ }^{29}$ Congressional Budget Office (1982). In discussing the reasons for the change in the outlook on the deficits between 1981 and 1983 . the Congressional Budget Office $(1983, p .18)$ says that, "Over the entire five-year period, 60 percent of the change in outlook from budget surpluses to budget deficits can be attributed to the failure of the economy to perform as projected two years ago." In addition, it says ( $p .20$ ) that, "Legislative actions are the second largest reason for differences between the two baselines, accounting for about 30 percent of the change over the five-year period."

æolt is possible that higher projected government budget deficits lead to greater expected infation, in which case higher deficits would cause higher nominal, but not necessarily real, interest rates.

s! See Wilcox (1983).
} 
Chort 5

\section{Cyclically Adjusted Budget Deficit and 1-Year Real Interest Rate}

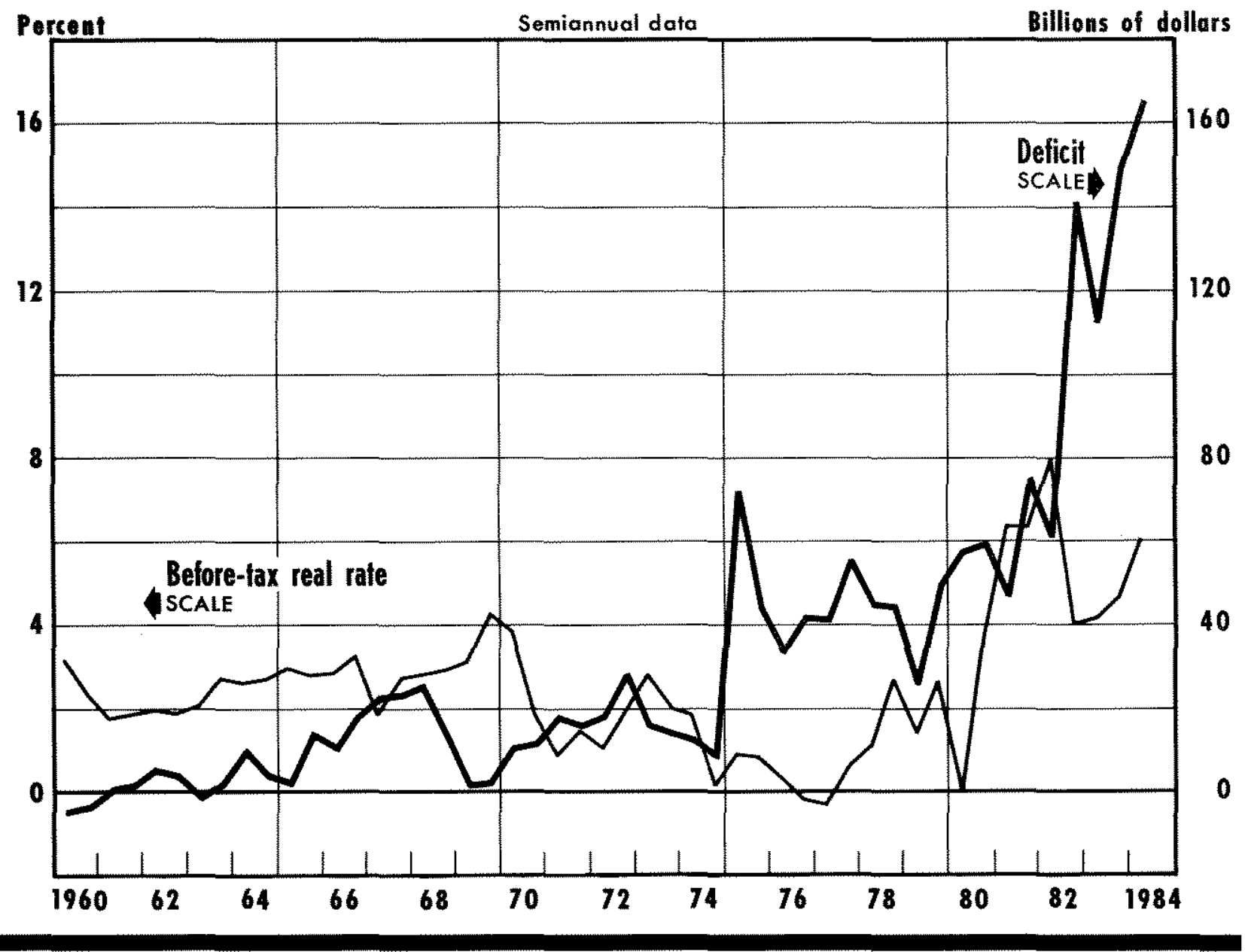

complementary energy inputs, which resulted in reduced demand for loanable funds and lower real interest rates. ${ }^{32}$

Once again, however, the timing of the recent rise in real interest rates fails to lend credence to the theory. During the period of most rapidly rising real interest rates in 1980 and the first half of 1981 , the relative price of energy was still rising rapidly as a result of the second oil crisis; the growth rate of the relative price of energy between IV/1979 and II/1981 was 18.3 percent $^{33}$

3zSee Tatom (1979) for a discussion of the impact of energy shocks on investment.

33 The measure of the relative price of energy is the producer price index for "fuels and related products and power" divided by the business sector deflator.
Reductions in the relative price of energy did not begin until late 1981, after most of the increase in real interest rates already had occurred.

\section{CONCLUSIONS}

The 1980s have seen unprecedented behavior in several key economic variables, the most notable being interest rates. According to estimates of real interest rates based on surveys of expected inflation, both short- and long-term real rates rose to record levels in 1981 and 1982 and, although they have declined somewhat since then, have not returned to the levels of the 1960s and $1970 \mathrm{~s}$.

A comparison of estimates of before- and after-tax real interest rates indicates that the overall pattern of 
their movements has been similar. The spread between the before- and after-tax real rates increased over much of the sample, however, as nominal interest rates (and expected inflation) increased. Therefore, after-tax real interest rates have not been nearly as high relative to previous experience as before-tax real rates. Nonetheless, they have been higher on average than they were in the 1960 s and much higher than in the $1970 \mathrm{~s}$.

The phenomenon most closely coincident with the rise in real rates was an increase in the variability of money growth, which increased economic uncertainty and the risk premium on interest rates. Major changes in current and projected government budget deficits and in tax policies happened after much of the upward shift in real interest rates already had occurred, but may have contributed to some additional upward movement. Changes in economic conditions have been a major influence on the movement of real interest rates since 1981; periods of slow growth or recession have produced falling real rates, while expansions have pushed real rates upward.

\section{REFERENCES}

Brown, W. W., and G. J. Santoni. "Monetary Growth and the Timing of Interest Rate Movements," this Review (Augusl/September 1983), pp. 16-25.

Carison, John A. "A Study of Price Forecasts," Annals of Economic and Social Measurement (Winter 1977), pp. 27-56.

Carison, Keith M. "The Mix of Monetary and Fiscal Policies: Conventional Wisdom Vs. Empirical Reality," this Review (October 1982), pp. $7-21$

"The Critical Role of Economic Assumptions in the Evaluation of Federal Budget Programs," this Review (October 1983), pp. 5-14.

Congressional Budget Office. Baseline Budget Projections: Fiscal Years 1982-1986 (U.S. Government Printing Office, July 1981).

\section{(GPO, February 1982)}

(GPO, February 1983).

Darby, Michaet R. "The Financial and Tax Effects of Monetary Policy on Interest Rates," Economic Inquiry (June 1975), pp. 266-76.
Ezrati, Milton J. "Inflationary Expectations, Economic Activity, Taxes, and interest Rates: Comment," American Economic Review (Seplember 1982), pp. 854-57.

Feldstein, Martin. 'Inflation, Income Taxes, and the Rate of Interest: A Theoretical Analysis," Amenican Economic Review (December 1976), pp. $809-20$.

Feldstein, Martin, and Lawrence Summers. "Inflation, Tax Rules, and the Long-Term Interest Rate," Brookings Papers on Economic Activity (1:1978), pp. $61-99$.

Fischer, Stanley. "On Activist Monetary Policy with Rational Expectations," in Stanley Fischer, ed., Rational Expectations and Economic Polfoy (The University of Chicago Press, 1980), pp, $211-47$.

Fisher, Irving. Appreciation and Interest (1896), Reprints of Economic Classics (Augustus M. Kelley, Bookseller, 1965 ).

Friedman, Milton, and Anna Jacobson Schwartz. A Monetary Hisfory of the United States 1867-1960 (Princeton University Press, 1963).

Hafer, R. W. "The Money-GNP Link: Assessing Altemative Transaction Measures," this Review (March 1984), pp. 19-27.

Hafer, R. W., and Scott E. Hein. "Monetary Policy and Short-Term Real Rates of Interest," this Review (March 1982), pp. 13-19.

Holland, A. Steven. "Does Higher Inflation Lead to More Uncertain Inflation?" this Review (February 1984), pp. 15-26.

Makin, John, and Vito Tanzi. "The Level and Volatility of Interest Rates in the United States: The Role of Expected Inftation, Real Rates, and Taxes," Working Paper No. 1167 (National Bureau of Economic Research, Juty 1983).

Mascaro, Angelo, and Allan H. Meltzer. "Long- and Short-Term interest Rates in a Pisky Wortd." Joumal of Monetary Economics (November 1983), pp. 485-518.

Mehra, Yash. "The Tax Effect, and the Recent Behaviour of the After-Tax Real Rate: Is It Too High?" Federal Reserve Bank of Richmond Economic Review (July/August 1984), pp. 8-20.

Mundell, Robert. "Inflation and Real Interest," Joumal of Pohtical Economy (June 1963), pp. 280-83.

Ott, Mack. "Depreciation, Inflation and Investment Incentives: The Effects of the Tax Acts of 1981 and 1982," this Review (November 1984), pp. $17-30$.

Santoni, G. J., and Couttenay C. Stone. "The Fed and the Real Rate of Interest," this Review (December 1982), pp. 8-18.

Tatom, John A. "Energy Prices and Capital Formation: 1972 1977," this Roview (May 1979), pp. 2-11.

"A Perspective on the Federal Deficit Problem," this Review (June/July 1984), pp. 5-17.

Tobin, James. "Money and Economic Growth," Econometrica (October 1965), pp. 671-84.

Wallich, Henry C. "Recent Techniques of Monetafy Policy," Federal Reserve Bank of Kansas City Economic Review (May 1984), pp. $21-30$.

Wilcox, James A. "Why Real Interest Rates Were So Low in the 1970 's," American Economic Review (March 1983), pp. 44-53. 